Article

\title{
Clinical Efficacy of Four In-Office Vital Tooth Bleaching Products with Different Concentrations of Hydrogen Peroxide: A Randomized, Quadruple-Blind Clinical Trial
}

\author{
Marta Peydro-Herrero, José María Montiel-Company® ${ }^{\circledR}$, Carlos Labaig-Rueda, \\ María Fernanda Solá-Ruiz $\mathbb{D}^{\mathbb{D}}$, Rubén Agustín-Panadero * ${ }^{\mathbb{D}}$ and José Amengual-Lorenzo \\ Department of Stomatology, Faculty of Medicine and Dentistry, University of Valencia, 46010 Valencia, Spain; \\ peyhemar@uv.es (M.P.-H.); jose.maria.montiel@uv.es (J.M.M.-C.); carlos.labaig@uv.es (C.L.-R.); \\ m.fernanda.sola@uv.es (M.F.S.-R.); jose.amengual@uv.es (J.A.-L.) \\ * Correspondence: ruben.agustin@uv.es; Tel.: +34-963-864-034
}

Received: 8 June 2020; Accepted: 2 July 2020; Published: 5 July 2020

check for updates

Featured Application: From this work, it is possible to establish the need to know the color parameters of the teeth to be bleached when you want to predict the results that can be obtained by teeth whitening.

\begin{abstract}
Background: Dental bleaching has become an everyday procedure for treating teeth presenting discoloration, as a therapy on its own or as a part of restorative dentistry. The most widely used bleaching products available for vital teeth are hydrogen peroxide and carbamide peroxide, marketed as a range of products adapted to different treatment modes. The purpose of the study was to evaluate the clinical whitening efficacy of four high-concentration bleaching products for vital teeth applied in single in-office sessions. Methods: This clinical trial included 40 patients divided into four groups according to the concentration of the hydrogen peroxide-based (HP) product used (Group 1: HP 35\%; Group 2: HP 37.5\%; Group 3: HP 38\%; Group 4: HP 40\%). Each patient received one in-office whitening treatment of maxillary and mandibular anterior teeth (incisors, canines, and premolars), making a total of 791 teeth. The color changes produced in central incisors and canines were measured. Results: All groups underwent significant color changes from initial to final evaluations for color parameters $L^{*}, a^{*}$, and $b^{*}$. No significant differences between the four groups were found for either the $\mathrm{L}^{*}$ or $\mathrm{a}^{*}$ parameters. Analysis of the $\mathrm{b}^{*}$ parameter found significant differences between the HP $38 \%$ group and the HP 35\% group. No significant differences in $\triangle \mathrm{E}$ were found between the four groups (ANOVA $p=0.174$ ). HP $38 \%$ obtained the highest $\triangle \mathrm{E}$ (4.63), while HP $40 \%$ obtained 4.01 . Conclusions: A single in-office whitening session, regardless of the bleaching product used, modifies tooth color effectively. All four products achieved increases in the $\mathrm{L}^{*}$ parameter and significant reductions in parameters $\mathrm{a}^{*}$ and $\mathrm{b}^{*}$. The $\Delta \mathrm{E}$ did not show significant differences between the four groups. In-office whitening with high concentration hydrogen-peroxide-based products was found to be an effective treatment for moderate and severe dental discoloration.
\end{abstract}

Keywords: combined vital tooth whitening; carbamide peroxide; tooth discoloration; dental bleaching; in-office; hydrogen peroxide 


\section{Introduction}

With patient demand for whiter teeth, dental bleaching has become a widespread conservative therapy for treating teeth presenting discoloration, as a single treatment or before placing a ceramic or resin composite restoration to improve the final overall color.

Among the bleaching products for vital teeth currently on the market, hydrogen-peroxide-based and carbamide-peroxide-based agents are the most widely used. The products vary in concentration (high concentrations for in-office use, low concentrations for use at home) and format, intended for different whitening procedures (in-office or at home) with different application methods [1-23]. In-office applications of bleaching agents with high concentrations of hydrogen peroxide (HP) are described as an effective and fast option indicated in cases of moderate or severe vital tooth discoloration that avoid prolonged home treatments with carbamide peroxide and dietary restrictions [3-6,10,14-17,19,21-23].

Several authors have demonstrated the efficacy of high concentration hydrogen peroxide when used as a bleaching agent in the office. Giachette et al. verified the effectiveness of a $38 \%$ hydrogen peroxide treatment [9]. Matis et al. evidenced the effectiveness of a $37.5 \%$ hydrogen peroxide treatment [5]. Monteiro et al. used a light-curing 35\% hydrogen peroxide treatment and obtained good results quickly [17]. Marson et al. studied the stabilization of the color with different whitening techniques in the office and achieved an important change in the color of the treated teeth [6].

Nevertheless, the wide range of products available for in-office whitening makes it difficult to decide which one to choose, as each could be more or less effective as a result of variations in concentration and application time. Moreover, no ranking of these products comparing their efficacy has ever been published. This would make it possible to opt for one or another according to the individual case and the patient's characteristics and needs.

In this context, there is a need to make objective, quantifiable evaluations of the tooth color obtained through the use of bleaching products. This would allow comparison of these products on the basis of valid data reported in clinical trials. In order to evaluate color, spectrophotometers have been introduced to identify the correct and objective color change in enamel surfaces [24-38].

The aim of this randomized quadruple-blind clinical trial was to objectively quantify the effects of four high-concentration dental whitening products of hydrogen peroxide for in-office use on vital teeth, following the application protocols recommended by the manufacturers.

\section{Materials and Methods}

This clinical trial included 40 patients randomly assigned to one of four treatment groups (10 per group). Each patient received a single in-office whitening treatment of maxillary and mandibular incisors, canines, and premolars (20 teeth in each patient, a total of 791 teeth due to nine missing teeth). Color changes were measured on six guide teeth (maxillary incisors and four canines). A product of different hydrogen peroxide concentration was used in each group: group 1 (G1): HP 35\%; group 2 (G2): HP 37.5\%; group 3 (G3): HP 38\%; and group 4 (G4): HP 40\%.

The study was approved by the Clinical Research Ethics Committee (CEIH) of the University of Valencia (Spain) with the procedural registration number 1279729. Each patient was provided with full information about the bleaching procedure, the trial's purpose, the structure, the commitment required from the participant, and the possible risks involved in treatment; all patients gave their informed consent to take part.

Accepting an alpha risk of 0.05 and a beta risk of 0.2 in a two-sided test, 55 teeth were necessary in each group to identify statistically significant differences between the four groups greater than or equal to $1.5 \Delta \mathrm{E}$ units. The common standard deviation was assumed to be 2.5 . A drop-out rate of $20 \%$ was anticipated.

Patients fulfilled the following inclusion criteria: aged between 19 and 65 years; absence of oral pathology; maxillary and mandibular incisors, canines, and premolars presenting colors appearing on the Vita Classical color guide (Vita) (guide samples arranged in order of luminosity), with a luminosity greater or equal to A3; teeth free of fillings. Smokers and patients who had received a whitening 
treatment on a previous occasion were excluded from the trial. The 40 patients were assigned to a group, using online randomization software (www.alazar.info). 10 patients in each of the four study groups. A splint was fabricated to position the device used to quantify color modification in the same area of each tooth (maxillary and mandibular central incisors and canines) [24].

Treatment began by removing bacterial plaque and any stains on the tooth surfaces with a nylon brush set in a rotary instrument at low speed, with non-abrasive toothpaste.

Anterior and premolar teeth were isolated with a double arch rubber dam (OptiDam, Kerr, Orange, California, USA), with the edges of the perforations inverted in the gingival sulci, and with silk ligatures on the tooth necks.

Each patient received a single in-office vital tooth whitening session, treating maxillary and mandibular incisors, canines, and premolars with one of the four hydrogen-peroxide-based (HP) products:

- Group 1: a light-activated hydrogen peroxide at a concentration of 35\% (Quick White kit clínica, Quick White), delivered as a powder and a liquid, which when mixed acquires a turquoise-colored gel consistency. Sixty teeth were treated with the gel, carrying out three applications of $10 \mathrm{~min}$ each. The gel was activated with a low-temperature LED lamp specifically designed for this purpose.

- Group 2: a chemically activated hydrogen peroxide agent at a concentration of $37.5 \%$ (Pola Office+ Southern Dental Industries), which is delivered in a double-parallel syringe; when mixed, it acquires a transparent bluish gel consistency. Fifty-eight teeth were treated with the gel, involving three applications of 8 min each.

- Group 3: a chemically activated hydrogen peroxide agent at a concentration of 38\% (PURE in-office bleaching, Axis Dental). It is delivered in a double-parallel syringe, which when mixed acquires a gel consistency and a red color. Fifty-seven teeth were treated, each receiving three applications of 15 min duration.

- Group 4: a chemically activated hydrogen peroxide treatment at a concentration of $40 \%$ (Boost. Ultradent), delivered in a double syringe. When mixed, it acquires a gel consistency and a red color. Fifty-six teeth were treated with the product, involving two applications of 20 min each.

After completing treatment, patients were advised of the importance of following the oral hygiene and dietary regimes that accompanied the bleaching treatment and the need to stop smoking for at least one week $[25,26]$. Intraoral digital photographs were taken before treatment and a week after the conclusion of the in-office bleaching session.

The EasyShade V spectrophotometer (Vita) positioned with previously fabricated splints were used to register tooth color according to the Vita Classical shade guide and CIELab color space parameters L* (luminosity), $\mathrm{a}^{*}$ (variations in red-green color axis), and $\mathrm{b}^{*}$ (variations in yellow-blue color axis) [27-34], before treatment and a week after the conclusion of the in-office whitening sessions. Using all these registers, the Euclidean distance $(\Delta \mathrm{E})$ between each two points of color in the CIELab space was calculated with the formula $\Delta \mathrm{E}=\left((\mathrm{Lf}-\mathrm{Li})^{2}+(\mathrm{af}-\mathrm{ai})^{2}+(\mathrm{bf}-\mathrm{bi})\right)^{1 / 2}$. Color measurements were taken of maxillary and mandibular central incisors and canines only, as these teeth give more reproducible data due to the larger crown sizes and flat vestibular surfaces [35].

Photographic records and color evaluations were performed one week after the conclusion of each in-office session. Color measurement was always performed by the same operator, who was blinded to each patient's group assignation.

The difference between initial color parameters or $\Delta \mathrm{E}$ and those obtained one week after the conclusion of whitening and the differences between means were calculated [36,37]. Confidence intervals were determined at $95 \%$. The distribution of means was normal (Kolmogorov-Smirnof test; $p>0.05)$. The Student's $t$ test was used to compare paired mean values; one-way variance analysis (one-way ANOVA) was used to compare four mean values. Analysis of covariance (ANCOVA) was applied in case of any need for adjustment for a covariable in comparison between means. Correlations 
were determined by means of Pearson's correlation coefficient (r). A forward stepwise linear regression model was created for multivariate analysis. In all statistical tests, significance was set as $p<0.05$.

\section{Results}

In comparisons between groups at the start of the trial, parameters, $L^{*}$ and $a^{*}$ showed significant differences, but $b^{*}$ did not show significant differences (Table 1). All groups underwent significant color changes in $\mathrm{L}^{*}, \mathrm{a}^{*}$, and $\mathrm{b}^{*}$ as a result of in-office bleaching between the initial and post-treatment evaluations.

Table 1. Initial and final $\mathrm{L}^{*}, \mathrm{a}^{*}$, and $\mathrm{b}^{*}$ values in the four study groups.

\begin{tabular}{lccccc}
\hline & $\begin{array}{c}\text { 35\% H2O2 + Light } \\
\text { Mean (CI-95\%) }\end{array}$ & $\begin{array}{c}\text { 37.5\% H2O2 Mean } \\
\text { (CI-95\%) }\end{array}$ & $\begin{array}{c}\text { 38\% H2O2 Mean } \\
\mathbf{( C I - 9 5 \% )}\end{array}$ & $\begin{array}{c}\mathbf{4 0 \%} \mathbf{H 2 O 2} \text { Mean } \\
\mathbf{( C I - 9 5 \% )}\end{array}$ & $\begin{array}{c}\text { Inter-Group } \\
\text { ANOVA Test }\end{array}$ \\
\hline $\mathbf{L}^{*}$ initial & $76.0(74.5,77.5)$ & $77.8(76.3,79.4)$ & $81.5(80.3,82.7)$ & $80.7(79.3,82.2)$ & $p<0.001$ \\
\hline $\mathbf{L}^{*}$ final & $78.9(77.4,80.4)$ & $80.2(78.7,81.6)$ & $83.4(82.2,84.5)$ & $82.9(81.5,84.3)$ & $p<0.001$ \\
\hline $\begin{array}{l}\text { Student T test for } \\
\text { paired samples }\end{array}$ & $p<0001$ & $p<0.001$ & $p<0.001$ & $p<0.001$ & \\
\hline $\boldsymbol{a}^{*}$ initial & $-0.06(-0.41,0.28)$ & $-0.46(-0.81,-0.12)$ & $-0.91(-1.24,-0.53)$ & $-0.77(-1.06,-0.49)$ & $p=0.002$ \\
\hline $\boldsymbol{a}^{*}$ final & $-0.32(-0.62,-0.02)$ & $-0.81(-1.05,-0.55)$ & $-1.31(-1.57,-1.04)$ & $-0.88(-1.14,-0.61)$ & $p<0.001$ \\
\hline $\begin{array}{l}\text { Student T test for } \\
\text { paired samples }\end{array}$ & $p=0.011$ & $p<0.001$ & $p=0.001$ & $p=0.203$ & \\
\hline $\boldsymbol{b}^{*}$ initial & $18.9(17.3,20.5)$ & $20.5(19.2,21.9)$ & $19.6(17.8,21.4)$ & $19.8(18.2,21.4)$ & $p=0.539$ \\
\hline $\boldsymbol{b}^{*}$ final & $17.8(16.4,19.2)$ & $18.1(17.0,19.3)$ & $17.0(15.6-18.5)$ & $18.6(17.2-19.9)$ & $p=0.438$ \\
\hline $\begin{array}{l}\text { Student T test for } \\
\text { paired samples }\end{array}$ & $p=0.007$ & $p<0.001$ & $p<0.001$ & $p<0.001$ & \\
\hline
\end{tabular}

Table 2 shows differences in mean color parameters between initial and post-treatment evaluations. No significant differences between the four groups were found for the $\mathrm{L}^{*}$ or $\mathrm{a}^{*}$ parameters. For the $\mathrm{b}^{*}$ parameter, the $35 \%$ HP group had a higher mean value than the $38 \%$ HP group.

Table 2. Differences in mean $\mathrm{L}^{*}, \mathrm{a}^{*}$, and $\mathrm{b}^{*}$ parameters and $\Delta \mathrm{E}$ from initial to final evaluations.

\begin{tabular}{|c|c|c|c|c|c|}
\hline & $\begin{array}{l}\text { 35\% H2O2 + Light } \\
\text { Mean (CI-95\%) }\end{array}$ & $\begin{array}{c}\text { 37.5\% H2O2 Mean } \\
\text { (CI-95\%) }\end{array}$ & $\begin{array}{l}38 \% \text { H2O2 Mean } \\
\text { (CI-95\%) }\end{array}$ & $\begin{array}{l}\text { 40\% } \mathrm{H} 2 \mathrm{O} 2 \text { Mean } \\
\text { (CI-95\%) }\end{array}$ & $\begin{array}{l}\text { Inter-Group } \\
\text { ANOVA Test }\end{array}$ \\
\hline Difference in $L^{*}$ & $2.92(2.11,3.72)$ & $2.32(1.48,3.15)$ & $1.84(1.30,2.37)$ & $2.17(1.20,3.16)$ & $p=0.286$ \\
\hline Difference in $a^{*}$ & $-0.26(-0.46,-0.06)$ & $-0.34(-0.51,-0.17)$ & $-0.40(-0.63,-0.17)$ & $-0.11(-0.28,-0.06)$ & $p=0.172$ \\
\hline Difference in $b^{*}$ & $-1.11(-1.90,-0.31)$ & $-2.39(-2.95,-1.84)$ & $2.57(-3.46,-1.68)$ & $-1.23(-1.81,-0.64)$ & $\begin{array}{l}p=0.004 \text { post hoc } \\
\text { Scheffe G3 vs. G1 }\end{array}$ \\
\hline$\Delta E$ & $4.73(4.05,5.42)$ & $4.57(3.97,5.17)$ & $4.26(3.52,5.01)$ & $3.76(3.13,4.40)$ & $p=0.174$ \\
\hline
\end{tabular}

Comparing $\Delta \mathrm{E}$ between the four bleaching products (Table 2), no significant differences were found between them (Figure 1) (one-way ANOVA $p=0.174$ ).

According to the univariate linear regression model with initial $\mathrm{L}^{*}$ and $\mathrm{a}^{*}$ values as covariables, while significant differences were found between groups at the initial valuation, adjusted $\Delta \mathrm{E}$ after treatment did not show significant differences between the four groups $(p=0.577)$. The group presenting the highest $\Delta \mathrm{E}$ was $38 \% \mathrm{HP}$ with a value of 4.63 , while $40 \% \mathrm{HP}$ gave a value of 4.01 .

When the whole sample was analyzed together, it was seen that $\Delta \mathrm{E}$ correlated negatively with initial $L^{*}$ value (Pearson $=-0.292$ ), whereby when the $L^{*}$ was higher, $\Delta E$ was lower. However, $L^{*}$ was positively correlated with initial $a^{*}($ Pearson $=0.267)$ and $b^{*}$ values $($ Pearson $=0.212)($ Figure 2$)$. 


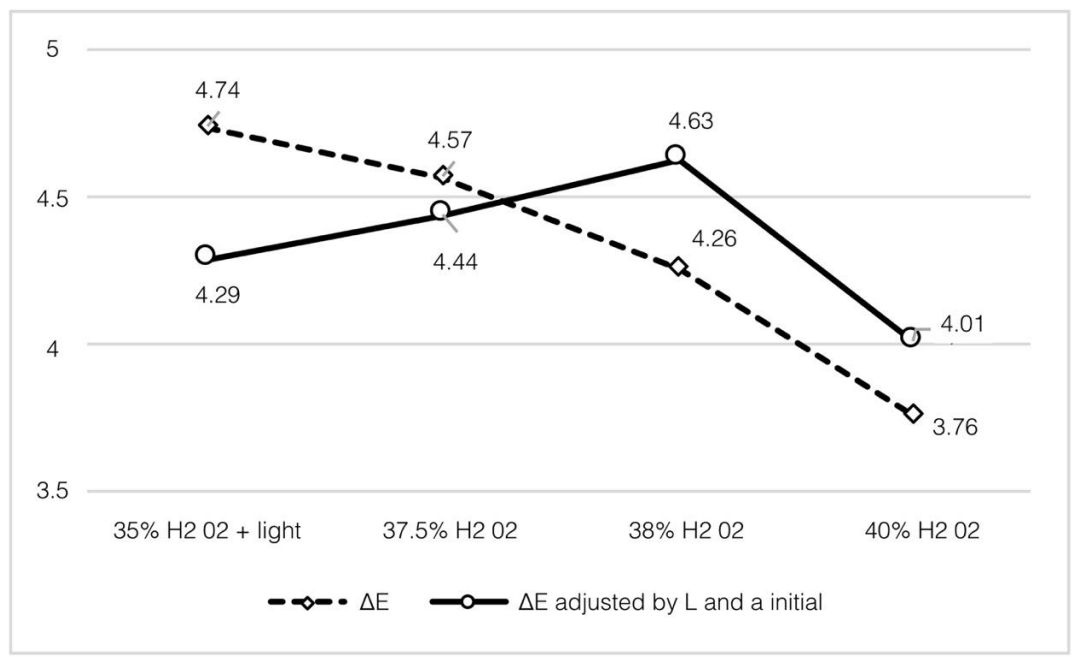

Figure 1. Non-adjusted comparison of initial $\Delta \mathrm{E}$ and initial adjusted $\mathrm{L}^{*}$ and $\mathrm{a}^{*}$ between groups.

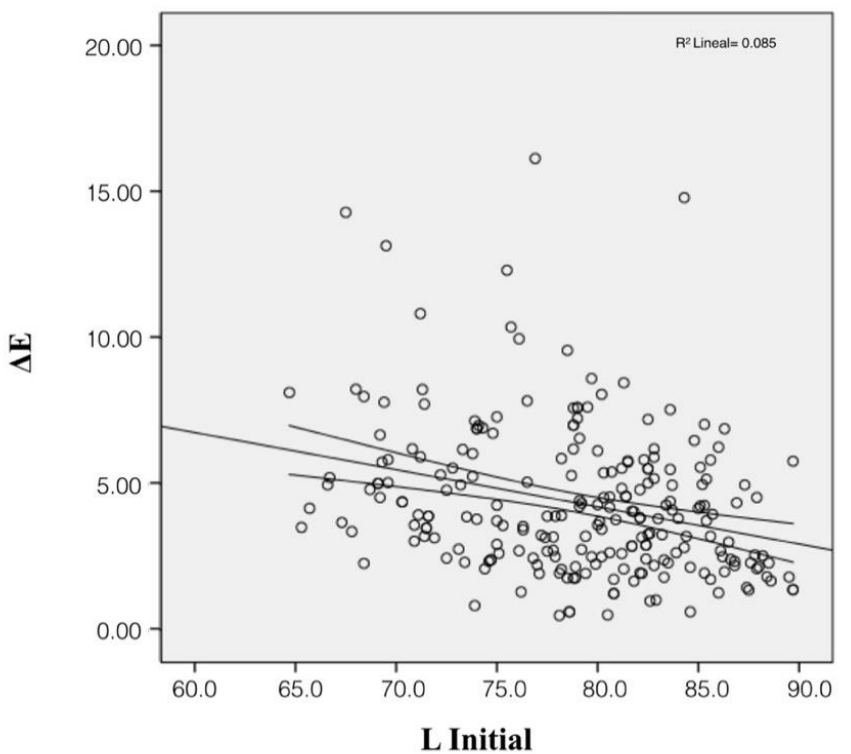

A

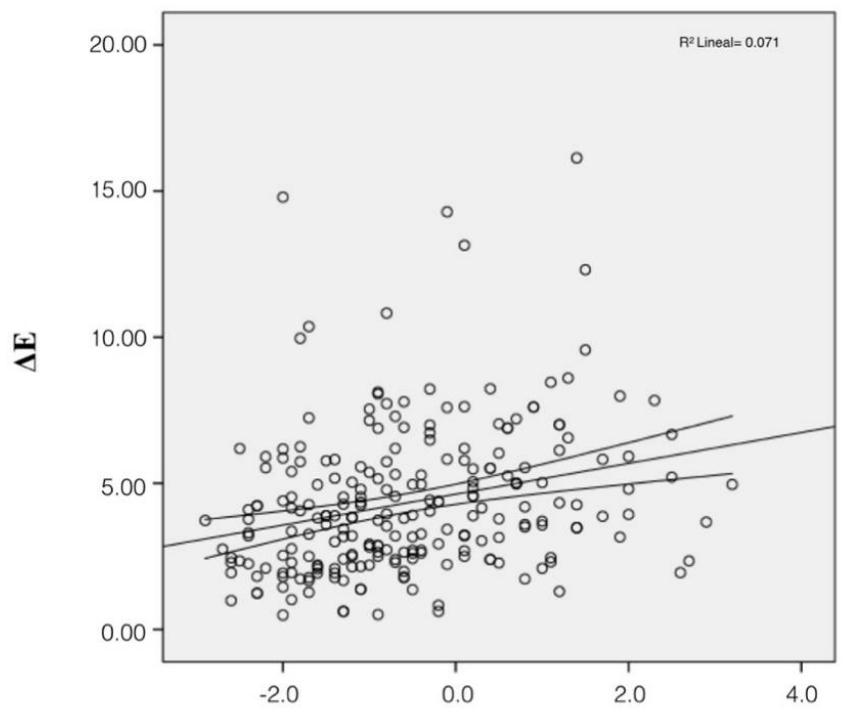

a Initial

Figure 2. Cont. 


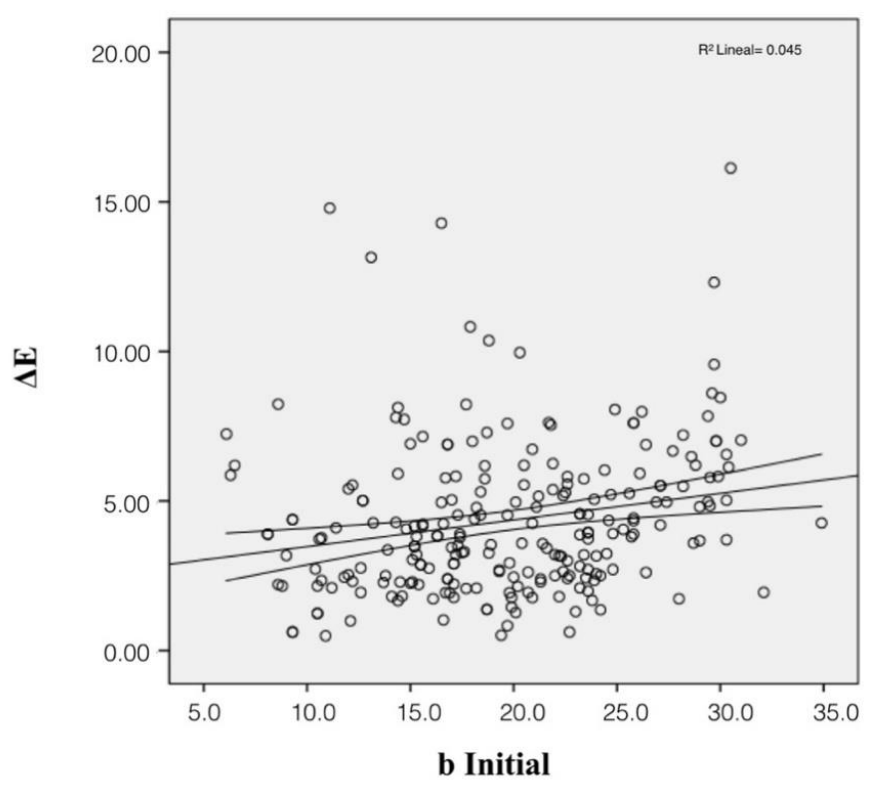

Figure 2. (A) Linear correlations between $\Delta \mathrm{E}$ and color parameter $\mathrm{L}^{*}$. (B) Linear correlations between $\Delta \mathrm{E}$ and color parameter $\mathrm{a}^{*}$. (C) Linear correlations between $\Delta \mathrm{E}$ and color parameter $\mathrm{b}^{*}$.

In the forward stepwise linear regression model ( $\mathrm{R}$ squared 0.149; $p<0.001$ ), initial $\Delta \mathrm{E}$ was the dependent variable; initial parameters $\mathrm{L}^{*}, \mathrm{a}^{*}$, and $\mathrm{b}^{*}$ were independent variables; and treatment groups were dummy variables. For this model, only initial $\mathrm{L}^{*}$ and $\mathrm{b}^{*}$ values were found to be significantly predictive variables $(p<0.001)$. The model constant was 13.42 and non-standardized beta coefficients for initial $L^{*}$ and $b^{*}$ were -0.142 and 0.107 , respectively. In this way, a predictive line equation could be established for the $\Delta \mathrm{E}$ of a single tooth undergoing bleaching treatment $=13.42+\left(\right.$ initial $\left.L^{*}-0.142\right)+$ (initial $\left.b^{*} \times 0.107\right)[38]$.

Patients did not present any unmanageable dental sensitivity during or after treatment, or any other secondary effects (Figures 3-6).

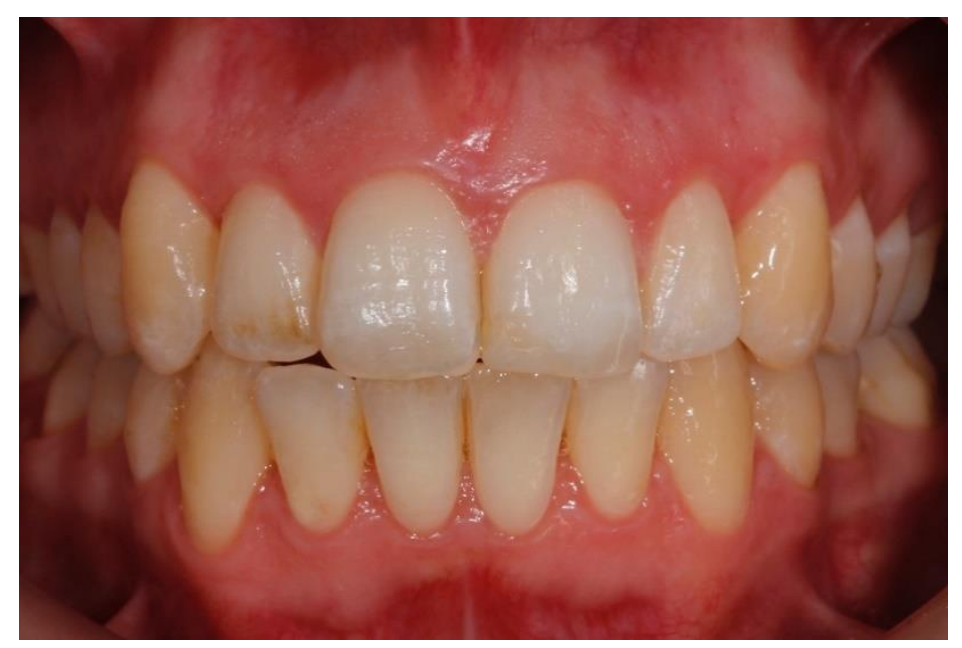

Figure 3. Cont. 


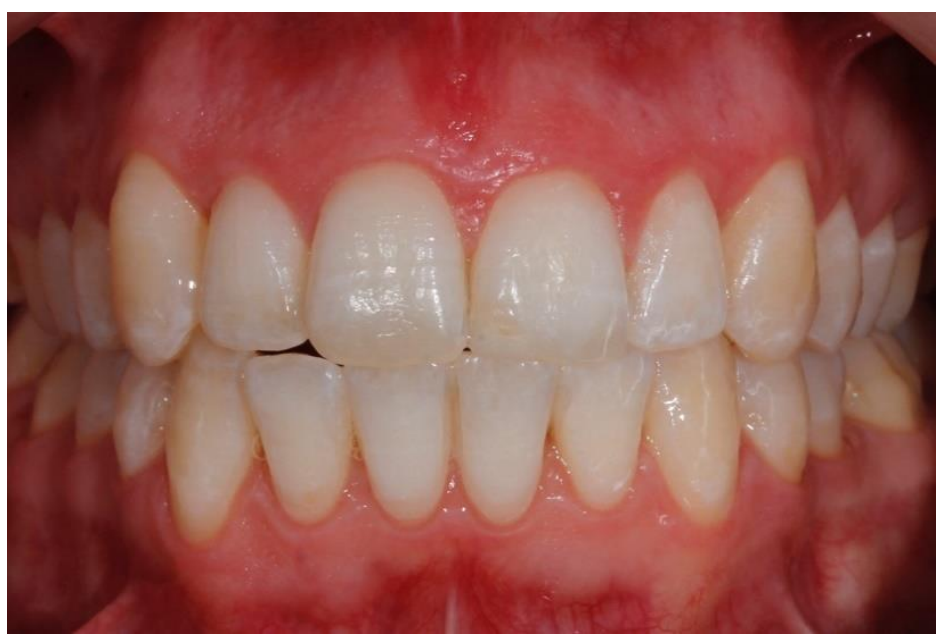

Figure 3. Group 1 patient (35\% HP, Quick White kit Clínica, Quick White): (A) pre-treatment image; (B) post-treatment image.

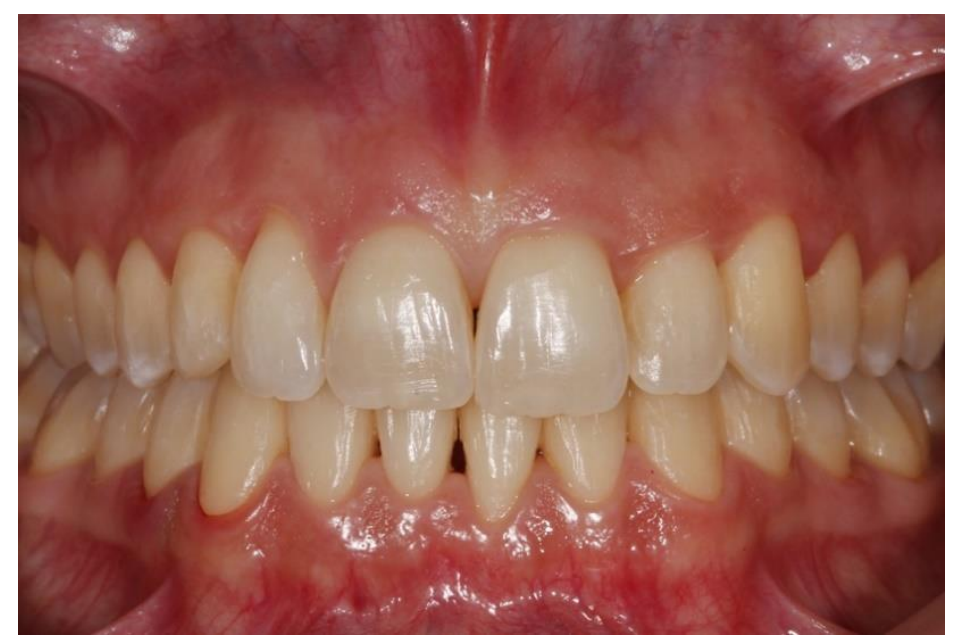

A

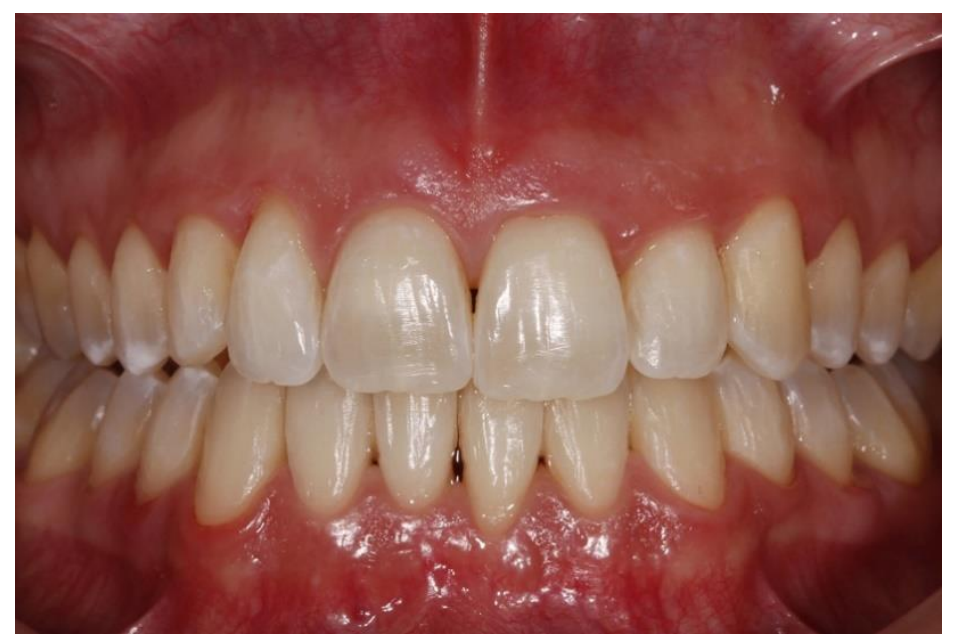

B

Figure 4. Group 2 patient (37.5\% HP, Pola Office + SDI): (A) pre-treatment image; (B) post-treatment image. 


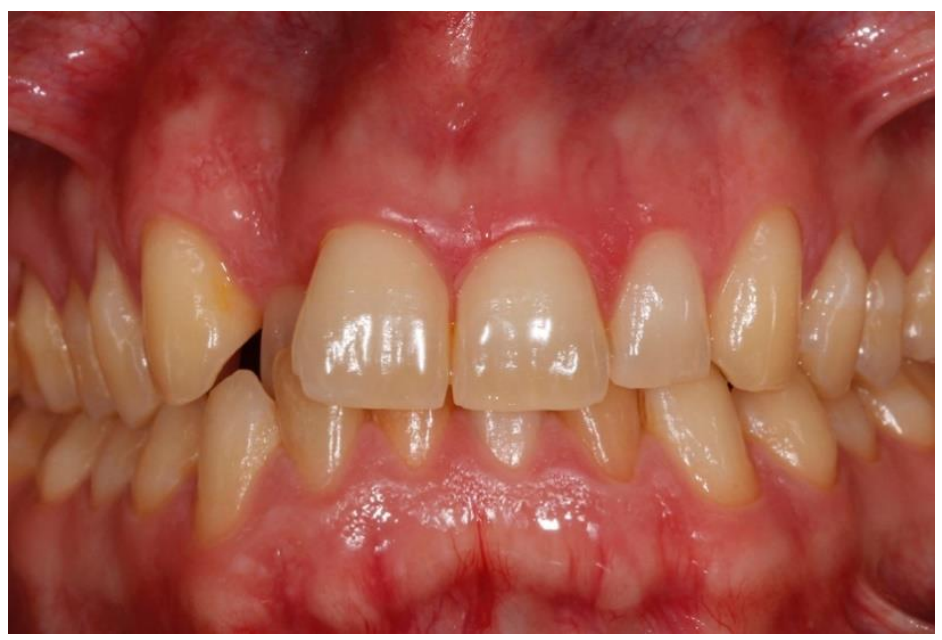

A

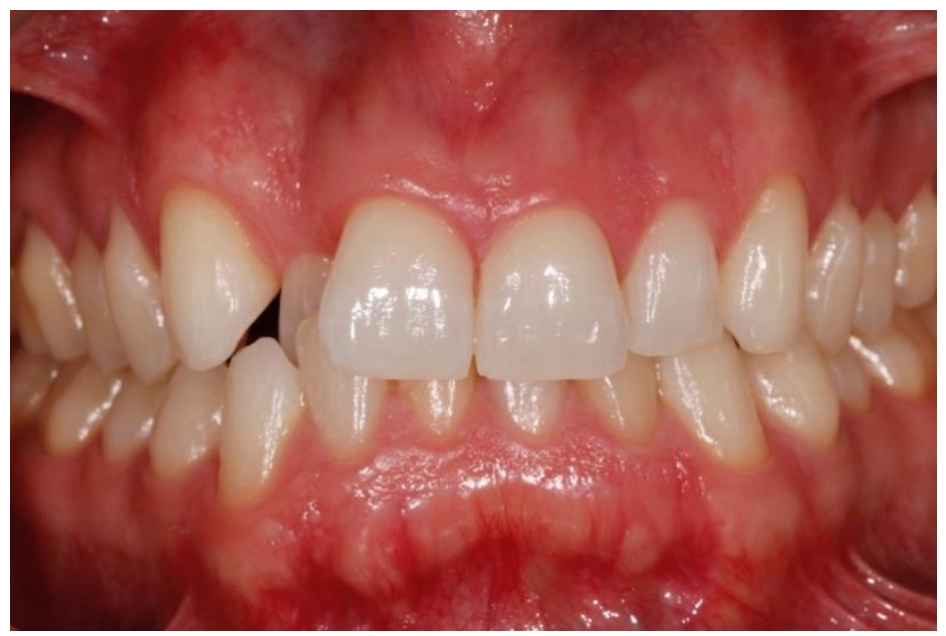

B

Figure 5. Group 3 patient (38\% HP, Pure, Axis Dental): (A) pre-treatment image; (B) post-treatment image.

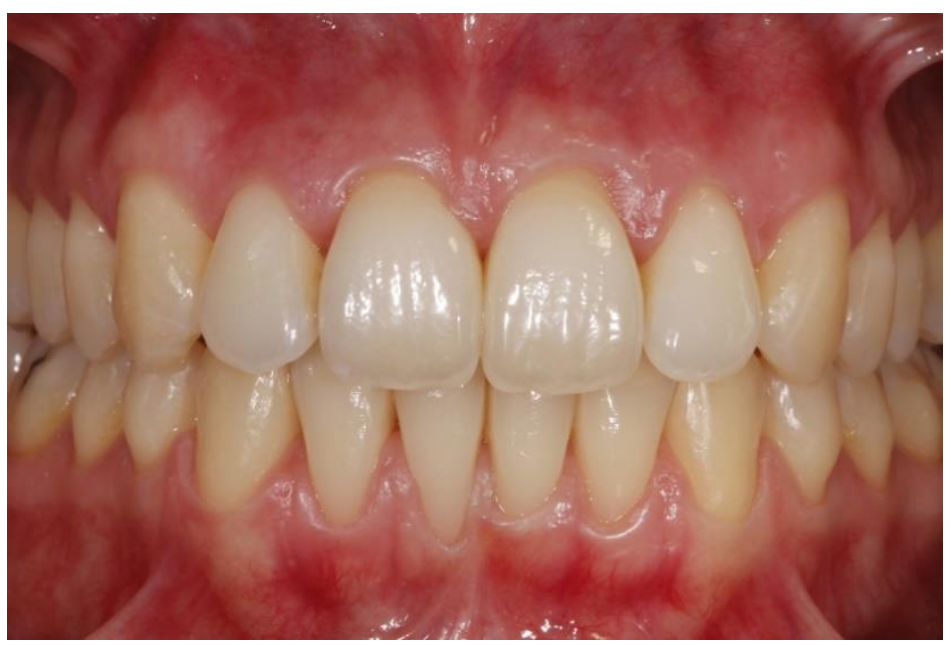

Figure 6. Cont. 


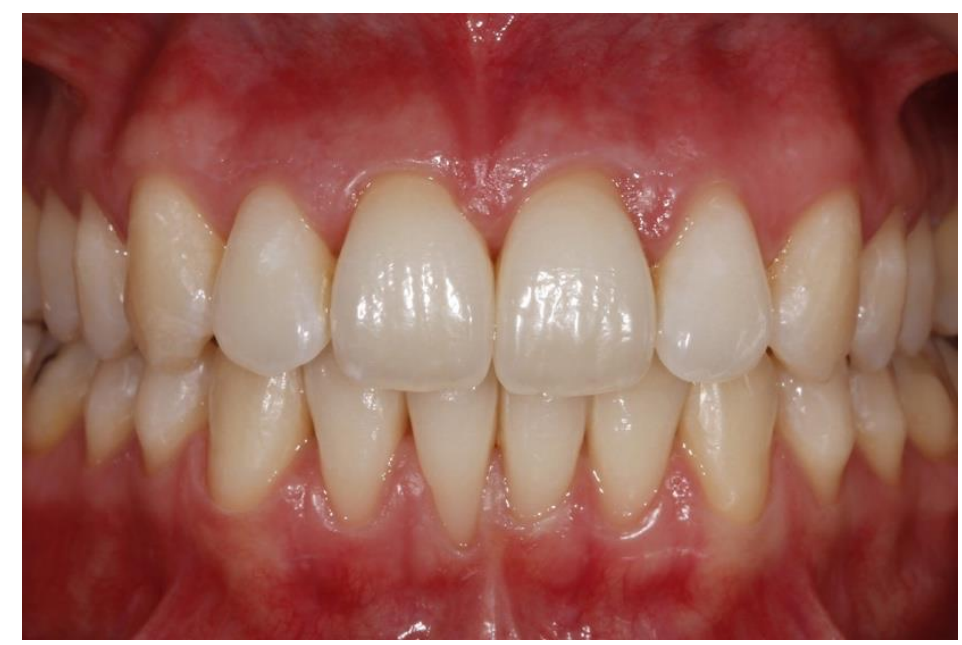

B

Figure 6. Group 4 patient (40\% HP, Boost, Ultradent): (A) pre-treatment image; (B) post-treatment image.

\section{Discussion}

The large number of whitening products available makes it difficult to select the most appropriate in each case; that is, the one that best suits the degree of discoloration, the type of patient and their lifestyle, or the one that produces the least adverse effects [13,14,39-41]. In cases in which it is intended to obtain effective and immediate color changes, among the different options available, whitening in consultation with agents with a high concentration of hydrogen peroxide is the most indicated option [5,18].

Among the range of products available on the market, the hydrogen-peroxide-based products tested in this trial were among those containing the highest concentrations of HP. The aim of the trial was to evaluate their efficacy in relation to the HP concentration.

Those patients who had teeth with Vita Classical colors (ordered by luminosity) greater than or equal to A3 were selected, which made it advisable to implement a treatment phase in the office to shorten the period of home treatment.

A spectrophotometer was used to evaluate color parameters objectively, so that the subjective judgment of an observer using color guides played no part in the trial [27-35]. Positioning splints were used for spectrophotometry, positioning the device in the same area of all the teeth evaluated, as a means of ensuring optimal reproducibility of the results [24,37].

It was decided to assess the bleaching effect after performing a single whitening session in the office with highly concentrated bleaching agents to minimize the potential risk of harm [42-44].

The use of light as a catalyst for the bleaching agent used in group 1 (PH 35) did not cause a significant decrease in the application time of the product, since it was applied for $30 \mathrm{~min}$, which was less than the $45 \mathrm{~min}$ required for the bleaching agent used in group 3 (PH 38) and the 40 min involved for the bleaching agent in group 4 ( $\mathrm{PH} \mathrm{40),} \mathrm{although} \mathrm{this} \mathrm{was} \mathrm{greater} \mathrm{than} \mathrm{the} 24 \mathrm{~min}$ application time for the bleaching agent used in group 2 ( $\mathrm{PH} 37.5 \%)$.

Among the difficulties encountered when implementing this study, it is worth mentioning the lack of homogeneity between the existing studies and trials and the methods used to process the results, making it difficult to make clear comparisons between them. For this reason, the present study chose to compare the mean $\Delta \mathrm{E}$ between current and previous studies, since this value is reported in all of them. Additionally, there was difficulty in obtaining a wide sample due to the unavailability of patients with teeth that met the color requirements that would allow them to be included in this study.

The efficacy of in-office vital tooth bleaching with high-concentration agents has been demonstrated in numerous studies [3-6,10,14-17,19,21-23]. A trial conducted by Zekonis et al. [3] carried out two sessions, each with three $10 \mathrm{~min}$ applications of a $35 \% \mathrm{HP}$ bleaching agent, obtaining a mean $\Delta \mathrm{E}$ of 
5.32. Marson et al. [6], using 35\% HP applied in two sessions consisting of three 15-min applications, obtained a mean $\Delta \mathrm{E}$ of 4 . Matis et al. [5] tested a $36 \% \mathrm{HP}$ bleaching agent and obtained a mean $\Delta \mathrm{E}$ of 3.09 after applying the product three times for $8 \mathrm{~min}$, and an $\Delta \mathrm{E}$ of 3.11 after a single application of $40 \mathrm{~min}$. All $\Delta \mathrm{E}$ values were similar to those achieved in the present trial. Llambés et al. [10], in an in vitro study, carried out two sessions each of three 8-min applications of a $37.5 \% \mathrm{HP}$ obtaining a mean $\Delta \mathrm{E}$ of 12.40. Faus et al. [19] found a mean $\Delta \mathrm{E}$ of 12.99 after four applications of 8 min each with $37.5 \%$ HP. In all these works, as in the present trial, the bleaching procedure was described as a treatment indicated for dental discoloration.

In addition to its tooth whitening effects, in-office bleaching offers a series of advantages in that treatment is carried out under the direct supervision of the dentist in a clinical setting and does not depend on the patient applying the treatment correctly at home [23]. It is also a much faster treatment, avoiding the prolonged contact between oral tissues and home bleaching products that treatment in domestic settings involves [18,42-44].

As for the whitening efficacy of the products tested in the present trial, all were found to be effective; no single product achieved better $\Delta \mathrm{E}$ results than the others. For this reason, other aspects should be considered when approaching in-office vital tooth bleaching [14]. These include the patient's initial color parameters, as patients who present high $L^{*}$ values or low $a^{*}$ and $b^{*}$ values will probably not obtain a significant color modification with this procedure, as the present findings suggest. In this sense, the predictive line equation described above can be a useful instrument when deciding whether this bleaching modality is the most indicated.

Lastly, it is important to recognize the need to carry out clinical and radiological check-ups of treated patients in order to detect any undesirable secondary effects (irritation, inflammation, ulcers, burns and necrosis of the gums and mucosa, dental hypersensitivity, allergy, enzymatic changes and pulpal inflammation, apoptosis, mutagenicity, carcinogenesis, teratogenicity, systemic toxicity, enamel and dentin alterations, periapical injuries and endodontic failures, external cervical resorption) [42-44]. Further research is necessary to broaden the information available about this type of treatment and the high-concentration HP-based products used.

\section{Conclusions}

1. In single in-office sessions, each of the four tested products for the vital dental bleaching was found to modify tooth color in an effective way.

2. All four products obtained significant increases in the luminosity parameter $\left(\mathrm{L}^{*}\right)$ and significant reductions in the red-green color axis $\left(\mathrm{a}^{*}\right)$ and in the yellow-blue color axis $\left(\mathrm{b}^{*}\right)$ parameters. Differences between initial color parameters and those obtained a week after the conclusion of whitening $(\Delta \mathrm{E})$ were not present significant.

3. The initial $\mathrm{L}^{*}$ and $\mathrm{b}^{*}$ values could determine the final $\Delta \mathrm{E}$ obtained. The lower the initial luminosity value is $\left(\mathrm{L}^{*}\right)$, the greater will be the values of $\Delta \mathrm{E}$ obtained a week after the conclusion of whitening; additionally, the greater the initial $\mathrm{b}^{*}$ value, the greater the final $\Delta \mathrm{E}$ will be.

4. Determination of tooth color parameters using a spectrophotometer before being bleached allows for a more predictable clinical solution.

Author Contributions: All of the authors contributed to the investigation, supervision, writing, review, and editing of the study. The study conceptualization was carried out by J.A.-L., M.P.-H., and R.A.-P. Data curation, data visualization, and analysis were performed by J.M.M.-C., C.L.-R., and M.F.S.-R. All authors have read and agreed to the published version of the manuscript.

Funding: This research received no external funding.

Conflicts of Interest: This manuscript has not been published and is not under consideration for publication elsewhere. We have no conflicts of interest to disclose and all authors have approved the manuscript and agreed to its submission. 


\section{References}

1. Haywood, V.B.; Heymann, H.O. Nightguard Vital Bleaching: How Safe Is It? Quintessence. Int. 1991, 22, 515-523. [PubMed]

2. Niederman, R.; Tantraphol, M.C.; Slinin, P.; Hayes, C.; Conway, S. Effectiveness of dentist-prescribed, home-applied tooth whitening. A meta analysis. J. Contemp. Dent. Pract. 2000, 1, 20-36. [CrossRef] [PubMed]

3. Zekonis, R.; Matis, B.A.; Cochran, M.A.; Al Shetri, S.E.; Eckert, G.J.; Carlson, T.J. Clinical evaluation of in-office and at-home bleaching treatments. Oper. Dent. 2003, 28, 114-121. [PubMed]

4. Deliperi, S.; Bardwell, D.N.; Papathanasiou, A. Clinical evaluation of a combined in-office and take-home bleaching system. J. Am. Dent. Assoc. 2004, 135, 628-634. [CrossRef]

5. Matis, B.A.; Cochran, M.A.; Franco, M.; Al-Ammar, W.; Eckert, G.J.; Stropes, M. Eight in-office tooth whitening systems evaluated in vivo: A pilot study. Oper. Dent. 2007, 32, 322-327. [CrossRef]

6. Marson, F.C.; Sensi, L.G.; Vieira, L.C.C.; Araújo, E. Clinical evaluation of in-office dental bleaching treatments with and without the use of light-activation sources. Oper. Dent. 2008, 33, 15-22. [CrossRef]

7. Ontiveros, J.C.; Paravina, R.D. Color change of vital teeth exposed to bleaching performed with and without supplementary light. J. Dent. 2009, 37, 840-847. [CrossRef]

8. Hasson, H.; Ismail, A.; Neiva, G. Home-Based Chemically-Induced Whitening of Teeth in Adults (Review). The Cochrane Collaboration; John Wiley \& Sons, Ltd.: Hoboken, NJ, USA, 2009.

9. Giachetti, L.; Bertini, F.; Bambi, C.; Nieri, M.; Russo, D.S. A randomized clinical trial comparing at-home and in-office tooth whitening techniques: A nine-month follow-up. J. Am. Dent. Assoc. 2010, 141, 1357-1364. [CrossRef]

10. Llambés, G.; Llena, C.; Amengual, J.; Forner, L. In vitro evaluation of the efficacy of two bleaching procedures. Med. Oral. Patol. Oral. Cir. Bucal. 2011, 16, 845-851. [CrossRef]

11. Radz, G.M. Effectiveness of a combined in-office and take-home whitening system for teeth shades A3. 5 to A4. Compend. Contin. Educ. Dent. 2014, 35, 696-700.

12. Rezende, M.; Ferri, L.; Kossatz, S.; Loguercio, A.D.; Reis, A. Combined bleaching technique using low and high hydrogen peroxide in-office bleaching gel. Oper. Dent. 2016, 41, 388-396. [CrossRef] [PubMed]

13. Luque-Martinez, I.; Reis, A.; Schroeder, M.; Muñoz, M.A.; Loguercio, A.D.; Masterson, D.; Maia, L.C. Comparison of efficacy of tray-delivered carbamide and hydrogen peroxide for at-home bleaching: A systematic review and meta-analysis. Clin. Oral. Invest. 2016, 20, 1419-1433. [CrossRef] [PubMed]

14. Geus, J.L.; Wambier, L.M.; Kossatz, S.; Loguercio, A.D.; Reis, A. At-home vs In-office Bleaching: A Systematic Review and Meta-analysis. Oper. Dent. 2016, 41, 341-356. [CrossRef] [PubMed]

15. Jie, N.; Fu-Cong, T.; Zu-Hua, W.; Adrian, U.Y.; Xiao-Yan, W. Original Comparison of efficacy and outcome satisfaction between in-office and home teeth bleaching in Chinese patients. J. Oral. Sci. 2017, 59, 527-532.

16. Rodrigues, J.L.; Rocha, P.S.; Pardim, S.L.; Machado, A.C.V.; Faria-e-Silva, A.L.; Seraidarian, P.I. Association between in-office and at-home tooth bleaching: A single blind randomized clinical trial. Braz. Dent. J. 2018, 29, 133-139. [CrossRef]

17. Monteiro, R.V.; Monteiro, J.S.; de Andrada Caldeira, M.A. Clinical evaluation of two in-office dental bleaching agents. Am. J. Dent. 2018, 31, 239-242.

18. Maran, B.M.; Burey, A.; Paris Matos, T.; Loguercio, A.D.; Reis, A. In-office dental bleaching with light vs. without light: A systematic review and meta-analysis. J. Dent. 2018, 70, 1-13. [CrossRef]

19. Faus-Matoses, V.; Palau-Martínez, I.; Amengual-Lorenzo, J.; Faus-Matoses, I.; Faus-Llácer, V.J. Bleaching in vital teeth: Combined treatment vs in-office treatment. J. Clin. Exp. Dent. 2019, 11, 754-758. [CrossRef]

20. Lilaj, B.; Dauti, R.; Agis, H.; Schmid-Schwap, M.; Franz, A.; Kanz, F.; Moritz, A.; Schedle, A.; Cvikl, B. Comparison of bleaching products with up to $6 \%$ and with more than $6 \%$ hydrogen peroxide: Whitening efficacy using BI and $\mathrm{WI}_{d}$ and side effects-An in vitro study. Front. Physiol. 2019, 21, 919. [CrossRef]

21. Papathanasiou, A.; Kastali, S.; Perry, R.D.; Kugel, G. Clinical evaluation of a 35\% hydrogen peroxide in-office whitening system. Compend. Contin. Educ. Dent. 2002, 23, 335-348.

22. Kugel, G.; Papathanasiou, A.; Williams, A.J.; Anderson, C.; Ferreira, S. Clinical evaluation of chemical and light-activated tooth whitening systems. Compend. Contin. Educ. Dent. 2006, 27, 54-62.

23. Barghi, N. Making a clinical decision for vital tooth bleaching: At home or in-office? Compend. Contin. Educ. Dent. 1998, 19, 831-840. [PubMed] 
24. Shimada, K.; Kakehashi, Y.; Matsumura, H.; Tanoue, N. In vivo quantitative evaluation of tooth color with hand-held colorimeter and custom template. J. Prosthet. Dent. 2004, 91, 389-391. [CrossRef]

25. Naik, S.; Tredwin, C.J.; Scully, C. Hydrogen peroxide tooth-whitening (bleaching): Review of safety in relation to possible carcinogenesis. Oral. Oncol. 2006, 42, 668-674. [CrossRef]

26. Da Costa Filho, L.C.; da Costa, C.C.; Soria, M.L.; Taga, R. Effect of home bleaching and smoking on marginal gingival epithelium proliferation: A histologic study in women. J. Oral. Pathol. Med. 2002, 31, 473-480. [CrossRef] [PubMed]

27. Goldstein, G.R.; Schmitt, G.W. Repeatability of a specially designed intraoral colorimeter. J. Prosthet. Dent. 1993, 696, 16-19. [CrossRef]

28. Douglas, R.D. Precision of in vivo colorimetric assessments of teeth. J. Prosthet. Dent. 1997, 7, 464-470. [CrossRef]

29. Horn, D.J.; Bulan, J.; Hicks, M.L. Sphere spectrophotometer versus human evaluation of tooth shade. J. Endod. 1998, 24, 786-790. [CrossRef]

30. Clark, D.M.; Hintz, J. Case report: In-office tooth whitening procedure with $35 \%$ carbamide peroxide evaluated by the Minolta CR-321 Chroma Meter. J. Esthet. Dent. 1998, 10, 37-42. [CrossRef]

31. Amaechi, B.T.; Higham, S.M. Development of a quantitative method to monitor the effect of a tooth whitening agent. J. Clin. Dent. 2002, 13, 100-103.

32. Paul, S.; Peter, A.; Pietrobon, N.; Hämmerle, C.H. Visual and spectrophotometric shade analysis of human teeth. J. Dent. Res. 2002, 81, 578-582. [CrossRef] [PubMed]

33. Luo, W.; Westland, S.; Ellwood, R.; Pretty, I.; Cheung, V. Development of a Whiteness Index for Dentistry. J. Dent. 2009, 37, 21-26. [CrossRef]

34. Hee-Kyung, K. Evaluation of the repeatability and matching accuracy between two identical intraoral spectrophotometers: An in vivo and in vitro study. J. Adv. Prosthodont. 2018, 10, 252-258.

35. Llena, C.; Lozano, E.; Amengual, J.; Forner, L. Reliability of two colors selection devices in matching and measuring tooth color. J. Contemp. Dent. Pract. 2011, 12, 19-23. [CrossRef] [PubMed]

36. Robertson, A.R.; Lozano, R.D.; Alman, D.H.; Orchard, S.E.; Keitch, J.A.; Connely, R.; Graham, L.A.; Acree, W.L.; John, R.S.; Hoban, R.F.; et al. CIE Recommendations on uniform color-spaces, color difference equations, and metric color terms. Color Res. Appl. 1977, 2, 5-6.

37. Greta, D.C.; Colosi, H.A.; Gasparik, C.; Dudea, D. Color comparison between non-vital and vital teeth. J. Adv. Prosthodont. 2018, 10, 218-226. [CrossRef]

38. Herrera, L.J.; Pulgar, R.; Santana, J.; Cardona, J.C.; Guillén, A.; Rojas, I.; Pérez, M.M. Prediction of color change after tooth bleaching using fuzzy logic for vita classical shades identification. Appl. Opt. 2010, 49, 422-429. [CrossRef]

39. Kwon, S.R.; Wertz, P.W. Review of the Mechanism of Tooth Whitening. J. Esthet. Restor. Dent. 2015, 27, 240-257. [CrossRef]

40. Sulieman, M. An overview of bleaching techniques: I. History, chemistry, safety and legal aspects. Dent. Update 2004, 31, 608-610, 612-614, 616. [CrossRef]

41. Joiner, A. The bleaching of teeth: A review of the literature. J. Dent. 2006, 34, 412-419. [CrossRef]

42. Powell, L.V.; Bales, D.J. Tooth Bleaching: Its effects on oral tissues. J. Am. Dent. Assoc. 1991, 122, 50-54. [CrossRef] [PubMed]

43. Floyd, R.A. The effect of peroxides and free radicals on body tissues. J. Am. Dent. Assoc. 1997, 128, 37-40. [CrossRef] [PubMed]

44. Dahl, J.E.; Pallesen, U. Tooth bleaching-A critical review of the biological aspects. Crit. Rev. Oral. Biol. Med. 2003, 14, 292-304. [CrossRef] [PubMed]

(C) 2020 by the authors. Licensee MDPI, Basel, Switzerland. This article is an open access article distributed under the terms and conditions of the Creative Commons Attribution (CC BY) license (http://creativecommons.org/licenses/by/4.0/). 